\title{
PERENCANAAN BADAN USAHA MILIK DESA (STUDI KASUS FUNGSI PERENCANAAN BUMDES DI KABUPATEN CIANJUR PROVINSI JAWA BARAT)
}

\author{
Krisna Puji Rahmayanti ${ }^{1,}$ Dhian Kusumawardhani ${ }^{2}$, Afiati Indri Wardani ${ }^{3}$ \\ ${ }^{1}$ Fakultas Ilmu Administrasi, Universitas Indonesia \\ ${ }^{2}$ Lembaga Ilmu Pengetahuan Indonesia \\ ${ }^{3}$ Fakultas Ilmu Administrasi, Universitas Indonesia
}

e-mail : ${ }^{1}$ krisnarahmayanti@ui.ac.id ${ }^{2}$ dhia002@lipi.go.id ${ }^{3}$ afiatiindriw@gmail.com

\begin{abstract}
Abstrak
Penelitian ini bertujuan untuk menganalisis fungsi perencanaan sebagai satu siklus dalam fungsi manajemen di BUMDes di Kabupaten Cianjur. Dengan menggunakan pendekatan kuantitativ, penelitian ini menggunakan metode pengumpulan data berupa survei. Metode random sampling digunakan untuk memilih sampel. Hasil penelitian menunjukkan bahwa fungsi perencanaan sudah dilaksanakan oleh sebagian besar BUMDes yang ditandai dengan adanya dokumen rencana strategis, adanya visi dan misi organisasi, adanya formulasi strategi, dan penyusunan perencanaan anggaran. Adanya fungsi perencanaan yang telah dilaksanakan oleh sebagian BUMDes menunjukkan bahwa BUMDes telah memiliki modal awal dalam fungsi manajemen. Namun demikian, masih adanya BUMDes yang belum memiliki dokumen rencana menunjukkan hal ini menjadi salah satu faktor yang menyebabkan berbagai fungsi manajemen yang belum berjalan. Untuk itu, penelitian lanjutan tentang fungsi manajemen diperlukan serta perlu adanya langkah untuk menyelesaikan permasalahan tersebut melalui penyusunan tata cara penyusunan rencana kerja yang dapat melibatkan Pemeirntah Daerah atau BUMDes lainnya.
\end{abstract}

Kata Kunci: Fungsi Perencanaan, Manajemen, BUMDes

\begin{abstract}
This study aims to analyse the planning function as part of the management function in BUMDes in Cianjur regency. Using quantitative approach, this study uses survei as data collectionmethod. Random sampling method is used to determine sample of the research. The result found that planning function have been conducted in most of BUMDes which several indicators such as the availability of strategic planning, goal setting establishment, and budgetting. The planning function of the BUMDes become the foundation of overall management function in the organization. However, there are several BUMDes which have not conduct planning function which can be one significant factor that affect the mismanagement of the BUMDes. Therefore, further research about the other planning function is critiqal. This research underline that a learning method from Local Government or BUMDes are potential as a call to action.
\end{abstract}

Keywords: Planning Fucntion, Management, BUMDes 


\section{A. PENDAHULUAN}

Pemerintah Indonesia berharap terdapat peningkatan kemandirian desa dengan adanya BUMDes. Untuk itu sejumlah regulasi telah disusun untuk mendukung implementasinya. Kementerian Dalam Negera telah mengatur melalui Peraturan Menteri Dalam Negeri Nomor 39 Tahun 2010 tentang Badan Usaha Milik Desa. Kemudian, melalui Peraturan Pemerintah Nomor 43 Tahun 2014 tentang Peraturan Pelaksanaan Undang-Undang Nomor 06 Tahun 2014 sebagaimana telah diubah melalui Peraturan Pemerintah Nomor 47 Tahun 2015. Selain itu, Kementerian Desa, Pembangunan Daerah Tertinggal dan Transmigrasi mengeluarkan Peraturan Menteri Nomor 4 Tahun 2015 tentang Pendirian, Pengurusan dan Pengelolaan dan Pembubaran Badan Usaha Milik Desa. Pemerintah Kabupaten Cianjur adalah salah satu kabupaten yang juga telah menurunkan landasan yuridis BUMDes tersebut dengan mengeluarkan Peraturan Daerah Nomor 03 Tahun 2012 tentang Pedoman tata Cara Pembentukan dan Pengelolaan Badan Usaha Milik Desa.

Keberhasilan BUMDes juga menjadi perhatian Pemerintah Kabupaten Cianjur. Penelitian sebelumnya menunjukkan bahwa keberadaan BUMDes menjadi harapan sebagai modal dalam pembangunan (Dariah, 2009: 148). Sementara itu di Kabupaten Cianjur, BUMDes diharapkan dapat mendorong perekonomian masyarakat desa (Radar Cianjur, 2017). Pemerintah Kabupaten Cianjur mengakui bahwa Pemerintah Kabupaten Cianjur telah melakukan pengawasan dan bantuan dan mendorong kualitas usaha terhadap BUMDes dan Badan pemberdayaan Masyarakat dan Pemerintah Desa (BPMPD) (RadarCianjur, 2016). Pembentukan BUMDes sebagaimana mengilhami Peraturan Daerah tentang Pembentukan dan Pengelolaan BUMDes di Kabupaten Cianjur bertujuan untuk meningkatkan pendapatan asli desa; mendorong berkembangnya kegiatan perekonomian masyarakat desa; meningkatkan kreativitas dan peluang usaha ekonomi produktif (berwirausaha) anggota masyarakat desa; dan mendorong berkembangnya usaha mikro sektor informal untuk penyerapan tenaga kerja bagi masyarakat di desa.

Namun demikian, pendirian BUMDes serta implementasi manajemennya masih menghadapi sejumlah kendala. Pemerintah Kabupaten Cianjur melalui Kepala Sub Bidang Bina Sarana dan Prasarana Perekonomian Desa BPMPD Kabupaten Cianjur Dedi Rinaldi mengatakan bahwa potensi desa yang bervariasi menghambat pembentukan BUMDes serta perlu adanya modal awal $51 \%$ yang berasal dari anggaran desa (BeritaCianjur, 2015). Untuk itu diakui bahwa dari total 354 desa yang tersebar di 32 kecamatan baru terdapat 35 desa yang sudah membentuk BUMDes. Pada tahun 2016, jumlah ini bertambah menjadi 54 desa desa dari 354 desa di Kabupaten Cianjur yang telah membentuk BUMDes (PikiranRakyat, 2017). Rata-rata Bumdes yang sudah berdiri bergerak pada bidang pengelolaan sarana air bersih, simpan pinjam, hasil pertanian serta membentuk pasar desa. Kepala Dinas Pemberdayaan Masyarakat dan pemerintahan Desa (DPMPD) Kabupaten Cianjur Tedi Artiawan menilai Bumdes di Cianjur masih 
${ }^{1}$ Fakultas Ilmu Administrasi, Universitas Indonesia

2 Lembaga Ilmu Pengetahuan Indonesia

${ }^{3}$ Fakultas Ilmu Administrasi, Universitas Indonesia

rendah karena hambatan sumber daya manusia dan pemasaran produk.

Sehubungan dengan kondisi tersebut, penelitian ini menilai bahwa perlu ada analisis fungsi manajemen khususnya tentang perencanaan sebagai tahap awal atau dasar dalam fungsi manajemen organisasi. Hal ini dilatarbelakangi sejumlah tantangan dalam manajemen organisasi untuk mewujudkan BUMDes. Pertama, terdapat optimisme dalam meningkatkan kapabilitas BUMDes namun demikian pedoman pengelolaan di peraturan daerah masih belum menjawab kompleksitas manajemen BUMDES (JabarNews, 2017). Kedua, pendamping desa yang diharapkan berdasarkan amanat regulasi maupun harapan berbagai sektor untuk mendampingi desa termasuk dalam pengelolaan BUMDES belum dapat berperan (PikiranRakyat, 2017). Ketiga, masih terdapat berbagai hambatan dalam implementasi manajemen BUMDES sebagaimana telah disebutkan misalnya terkait pengembangan produk, pemasaran, dan sumber daya manusia.

Kondisi faktual tersebut sangat ironis mengingat bahwa pengelolaan BUMDES sangat membutuhkan dukungan fungsi manajemen. Manajemen meliputi fungis perencanaan, pengorganisasian, pemimpinan, dan pengawasan atas sumbersumber organisasi (manusia dan barang) untuk mencapai tujuan organisasi yang efektif dan efisien (Jones \& George, 2007). Robbin (2001) menilai bahwa upaya koordinasi dalam manajemen bertujuan untuk mencapai tujuan organisasi dengan efektif dan efisien. Dalam siklus manajemen tersebut, perencanaan sebagai fungsi yang penting dalam keberlanjutan siklus fungsi manajemen. Untuk itulah penelitian ini berupaya untuk menganalisis fungsi manajemen dari BUMDes di Kabupaten Cianjur Provinsi Jawa Barat sebagai upaya pertama untuk mengkaji implementasi BUMDes.

\section{LANDASAN TEORITIS}

Fungsi manajemen terdiri atas fungsi Perencanaan (Planning), Pengorganisasian (Organizing), Pemimpinan (Leading) dan Pengawasan (Controlling). Keempat fungsi tersebut terkenal dengan akronim POLC. Fungsi-fungsi manajemen POLC merupakan fungsi manajemen yang terkini.

Sementara itu, Bumdes sebagai lembaga usaha desa yang berfungsi untuk memberikan pelayanan sekaligus untuk meningkatkan pendapatan ekonomi masyarakat. Maryunani (2008: 35 dalam Ar Rahman 2015:6) menyebutkan bahwa Bumdes merupakan lembaga yang dikelola oleh masyarakat dan pemerintahan desa dengan tujuan untuk membangun ekonomi desa dan menjalin kerekatan sosial masyarakat desa. Pembentukan Bumdes tidak terlepas dari kebutuhan dan potensi yang ada di masing-masing desa. Peneliti lain Hardijono, dkk (2014: 23) lebih melihat Bumdes sebagai institusi baru yang nomenklaturnya kelembagaannnya merupakan penyederhanaan bentuk dari BUMN maupun BUMD. Ini disebabkan dari beberapa aspek seperti tujuan Bumdes dalam sebagai upaya untuk meningkatkan pendapatan asli desa seringkali disamakan dengan kontribusi BUMN ke Anggaran Pembangunan dan Belanja Negara atau kontribusi BUMD ke Anggaran Pendapatan daan Belanja Daerah (APBD). 
${ }^{1}$ Fakultas Ilmu Administrasi, Universitas Indonesia

2 Lembaga Ilmu Pengetahuan Indonesia

${ }^{3}$ Fakultas Ilmu Administrasi, Universitas Indonesia

Chrisman dan Paredo (2006: 310) mengemukakan konsep Badan Usaha Berbasis Masyarakat atau dikenal dengan Community Based Enterprises sebagai strategi untuk mengatasi kemiskinan di negara berkembang. CBE merupakan badan usaha yang didirikan oleh masyarkat yang bertujuan bagi penciptaan kesejahteraan sosial ekonomi masyarakat setempat . Beberapa ciri yang melekat pada CBE antara lain : berbasis pada keahlian yang dimiliki masyarakat setempat, memiliki beberapa tujuan seperti tujuan sosial, ekonomi dan budaya yang dilakukan secara simultan, dan sangat tergantung pada partisipasi masyarakat yang menjadi anggotanya.

Padahal jika dikaji dari beberapa penelitian terdahulu maka terlihat berbagai aspek yang selama ini melekat pada Bumdes dan telah diteliti secara mendalam. Sebagai contoh, penelitian Samidi, dkk (2015) tentang Peranan Bumdes dalam Peningkatan Ekonomi Masyarakat di Desa Pakan Tabih Kecamatan Kepenuhan Hulu Kabupaten Rokan Hulu menyimpulkan tentang belum maksimalnya peran Bumdes untuk meningkatkan ekonomi masyarakat di desa tersebut. Ini disebabkan oleh tidak semua bidang perdagangan yang menjadi anggota Bumdes menikmati keberadaan Bumdes karena sector perkebunan karet justru belum terlihat peningkatan ekonominya.

Salah satu faktor yang menjadi penyebab adalah lemahnya sistem pengawasan pada penggunaan dana, maupun faktor internal dari sector perkebunan karet yang sulit menentukan harga karena faktor cuaca. Kelebihan dari penelitian ini adalah digunakannya metode kuantitatif dengan penyebaran kuesioner dan metode kualitatif pada analisis deskriptif. Namun demikian, dalam kesimpulannya penelitian ini justru kurang melakukan eksplorasi secara mendalam terhadap faktor penyebab kurangnya sector perkebunan karet dalam pemanfaatan pinjaman Bumdes. Peneliti hanya melihat dari aspek produksi dan budidaya perkebunan kelapa sebagai faktor yang mempengaruhi fluktuasi harga namun melupakan aspek dari kelembagaan dan mekanisme penyaluran dana Bumdes sendiri.

Selanjutnya penelitian yang dilakukan oleh Ramadana, dkk (2013) yang dilakukan oleh Ramadana, dkk dengan judul Keberadaan Bumdes sebagai penguatan EKonomi Desa : Studi Kasus di Desa Landungsari, Kecamatan Dau, Kabupaten Malang menujukkan bahwa pendirian Bumdes hanya sebatas papan nama saja, karena dalam implementasinya tidak semua Bumdesa dapat berjalan dan memberikan kontribusi pada Pendapatan Asli Desa. Padahal dari sisi legislasi operasional yang mengatur pembentukan Bumdes di desa ini sudah dipayungi oleh Peraturan Daerah dan Peraturan Desa. Dengan menggunakan metode kualitatif deskriptif penelitian ini berhasil mengidentifikasi beberapa faktor kelemahan Bumdes di desa Landungsari, seperti pada aspek minimnya permodalan dan jumlah badan usaha yang terlalu banyak sampai justru berakibat pada ketidakberlanjutan badan-badan usaha ini. Sayangnya, penelitian tidak memberikan deskripsi tentang seberapa minimnya dana dan sumber hibah yang diperoleh oleh Bumdes Landungsari. 
${ }^{1}$ Fakultas Ilmu Administrasi, Universitas Indonesia

${ }^{2}$ Lembaga Ilmu Pengetahuan Indonesia

${ }^{3}$ Fakultas Ilmu Administrasi, Universitas Indonesia

Penelitian selanjutnya berjudul "Economic Independence Of The Village Through Institutional Village Enterprises (BUMDes)" yang dilakukan oleh Hardjono, dkk (2014) memberikan analisis yang mendalam tentang fenomena kelembagaan Bumdes dari sisi tata kelolanya. Dengan menggunakan metode kualitatif melalui pendekatan fenomenologi dan lokus penelitian di 3 desa Kabupaten Malang Jawa Timur dan mengambil studi kasus pada tata kelola Bumdes bidang pengairan penelitian ini menunjukkan bahwa secara kelembagaan Bumdes bertujuan untuk memaksimalkan keuntungan dalam bentuk laba dan memprioritaskan prinsip sosial kepada anggotanya yang terdiri dari masyarakat desa.

Ditambahkan pula, penelitian ini juga menemukan bahwa struktur organisasi Bumdes yang berada di luar pemerintahan desa tidak selalu berujung pada efisiensi dan stabilitas. Terakhir, ini menemukan bahwa penduduk desa yang ditugaskan sebagai personil Bumdes memiliki motivasi dan orientasi yang tidak berbasis materi atau finansial semata tetapi lebih kepada perasaan ingin dihargai baik secara politik dan sosial. Beberapa proposisi yang menjadi temuan dalam peneliti memiliki tingkat analisis yang sangat baik dan mendalam sayangnya tidak banyak dijelaskan bagaimana mekanisme struktur organisasi yang terpisah terhadap faktor efisiensi dan efektivitas.

Penelitian yang Hidayati (2015) menyimpulkan bahwa faktor sumberdaya manusia pengelola Bumdes menjadi kendala utama bagi pengembangan organisasi Bumdes. Ini disebabkan hampir sebagian besar pengelola atau manajer Bumdes tidak memiliki pengalaman atau latar belakang pendidikan yang sesuai dengan pengelolaan Bumdes. Dengan menggunakan pendekatan kualitatif dan mengambil lokus penelitian di Kabupaten Jombang Jawa Timur. Meskipun penelitian memiliki keunggulan dari sisi alat analisis model logik dengan menganalisis kinerja Bumdes dari input, process dan output, namun sayangnya, peneliti terlalu berfokus kepada kendala input dibandingkan dengan proses dan output. Akibatnya, penelitian kurang seimbang dalam menganalisis kelemahan sisi proses dan outputnya. Ditambahkan pula, dari aspek pengumpulan data peneliti kurang mengeksplorasi siapa saja informan yang dilibatkan yang berdampak pada keakuratan hasil penelitian.

Hasil penelitian Prafitri, dkk (2018) menemukan bahwa peran kepala desa dalam proses penyusunan dan komunikasi perencanaan bisnis, pelimpahan wewenang dalam permodalan, komitmen transparansi dan akuntabilitas para pengurus dalam sistem pelaporan dan kerja sama dari berbagai stakeholder untuk memotivasi pengurus dalam mengelola BUM Desa demi kesejahteraan desa merupakan prasyarat manajemen bisnis pemerintah desa melalui Bumdes. Dengan menggunakan pendekatan kualitatif dan melibatkan beberapa di Desa Serang, Kecamatan Karangreja, Kabupaten Purbalingga dan Desa Pernasidi, Kecamatan Cilongok, Kabupaten Banyumas. Meskipun melibatkan beberapa desa namun sayangnya peneliti terlalu mengeneralisasi hasil penelitiannya, sehingga keunggulan dari pendekatan kualitatif menjadi kurang 
${ }^{1}$ Fakultas Ilmu Administrasi, Universitas Indonesia

${ }^{2}$ Lembaga Ilmu Pengetahuan Indonesia

${ }^{3}$ Fakultas Ilmu Administrasi, Universitas Indonesia

menonjol pada kesimpulan hasil penelitian.

Pada kelembagaan Bumdes beberapa ciri dari $\mathrm{CBE}$ ini terlihat dari beberapa aspek seperti pemanfaatan tenaga kerja di desa, keuntungan yang diperoleh bagi masyarakat desa dan penyerta modal, pengelolaannya berdasarkan atas asas kekeluargaan dan kegotongroyongan serta tata nilai yang berkembang di masyarakat dan dikelola bersama oleh masyarat desa, serta pengambilan keputusan dan penyelesaian masalah dilakukan melalui musyawarah desa. Perbedaan konsep CBE dengan Bumdes adalah

Pendirian BUMDes dilandasi oleh UU No. 32 tahun 2004 tentang Pemerintahan Daerah dan PP No. 72 Tahun 2005 tentang Desa. Namun kemudian, seiring dengan perkembangan UU Desa Nomor 6 tahun 2014 maka terlihat bahwa pada UU Nomor 6 tahun 2014 terdapat tiga pasal yang mengatur Bumdes yaitu pada pasal 87 ayat (1) yang menyebutkan bahwa Desa dapat mendirikan Badan Usaha Milik Desa yang disebut dengan BUM Desa; ayat (2) yang mengatur tentang semangat gotong royong dan asas kekeluargaan sebagai landasan pembentukan Bumdes. Kemudian, ayat (3) Bumdes dapat menjalankan usaha di bidang ekonomi dan/atau pelayanan umum sesuai dengan ketentuan peraturan perundang-undangan.

Pasal 88 ayat (1) Pendirian Bumdes disepakati melalui Musyawarah Desa; ayat (2) Pendirian Bumdes ditetapkan dengan Peraturan desa. Pasal 89 hasil usaha Bumdes dimanfaatkan untuk : (1) pengembangan usaha dan (2) pembangunan desa, pemberdayaan masyarakat desa dan pemberian bantuan untuk masyarakat miskin melalui hibah, bantuan social, dan kegiatan dana bergulir yang ditetapkan oleh Anggaran Pendapatan dan Belanja Desa.

Pasal 90 Pemerintah, Pemerintah Daerah Provinsi, Pemerintah Kabupaten/Kota dan Pemerintah desa mendorong perkembangan Bumdes dengan (1) memberikan hibah atau akses permodalan; (2) melakukan pendampingan teknis dan akses ke pasar dan memprioritaskan Bumdes dalam pengelolaan sumber daya alam di desa.

Dari isi ketentuan tersebut maka Bumdes memiliki ciri CBE seperti yang telah disebutkan sebelumnya, meskipun terdapat beberapa pebedaan lain seperti adanya unsur pemerintah dalam kegiatan tata kelola baik dari sisi perencanaan maupun pengawasannya.

\section{B. METODE PENELITIAN}

Penelitian ini menggunakan pendekatan deskriptif. Metode pengumpulan data sudah dilaksanakan dengan metode survei. Populasi dalam penelitian ini adalah BUMDes yang telah disahkan melalui Peraturan Desa atau regulasi yang setara. Berdasarkan data terdapat 54 desa yang telah memiliki peraturan setingkat desa untuk menopang implementasi BUMDes. Penelitian ini memiliki confidence level $86 \%$ sehingga jumlah keterwakilan sampel 26 desa sesuai dengan perhitungan rumus Slovin.

$$
\begin{aligned}
\mathrm{n} & =\mathrm{N} /\left(1+\mathrm{N} \mathrm{e}^{2}\right) \\
& =54 /\left(1+54 * 0.14^{2}\right) \\
& =26
\end{aligned}
$$


${ }^{1}$ Fakultas Ilmu Administrasi, Universitas Indonesia

${ }^{2}$ Lembaga Ilmu Pengetahuan Indonesia

${ }^{3}$ Fakultas Ilmu Administrasi, Universitas Indonesia

Penelitian ini mengkaji 27 sampel dari BUMDes yang telah berdiri dan memiliki landasan hukum setingkat Pemerintah Desa. Sampel tersebut dipilih secara acak berdasarkan daftar BUMDes yang diperoleh dari Badan Pemberdayaan Masyarakat Desa (BPMD) Kabupaten Cianjur.

Penelitian ini menggunakan fungsi perencanaan sebagai bagian dari siklus fungsi-fungsi manajemen (Jones \& George, 2007). Berikut adalah operasionalisasi konsep dari fungsi perencanaan sebagai bagian dari teori fungsi manajemen.

\begin{tabular}{lll}
\hline Teori & Dimensi & Indikator \\
\hline & Tersedianya \\
& dokumen \\
& rencana \\
& strategis \\
& tahunan -5 \\
& & tahun \\
& & Tersedianya \\
& & dokumen \\
Fungsi- & Perencanaan & rencana \\
fungsi & & strategis yang \\
manajemen & & memuat visi \\
(Jones \& & & dan misi \\
George, & & Tersedianya \\
2007) & formulasi \\
& strategi dalam \\
& dokumen \\
& perencanaan \\
\hline & Tersedianya \\
& perencanaan \\
& anggaran \\
& dalam rencana \\
& strategis \\
\hline
\end{tabular}

\section{HASIL DAN PEMBAHASAN}

Dari 27 sampel, mayoritas BUMDes bergerak di bidang perdagangan. Terdapat $57 \%$ dari total jenis usaha yang dimiliki bergerak di bidang perdagangan misalnya jual beli telur, pakan ayam, kios, sembako, jual beli hasil pertanian, penyediaan obatobatan pertanian, heler padi, pembuatan produk gula semut, jual beli alat tulis kantor, dan pengemasa teh. Selain penjualan, terdapat juga pelayanan jasa sosial, simpan pinjam, jasa broker, dan persewaan. Melihat jenis usaha ini, perlu juga ada pembinaan dari Supra Desa (Pemerintah Kabupaten / Provinsi) yang mendorong inisiatif masyarakat termasuk mengajak penyusunan BUMDes yang tidak hanya befrungsi sebagai penggerak ekonomi dan tetapi juga dalam bidang sosial kemasyarakatan (PATTIRO, 2016:6).

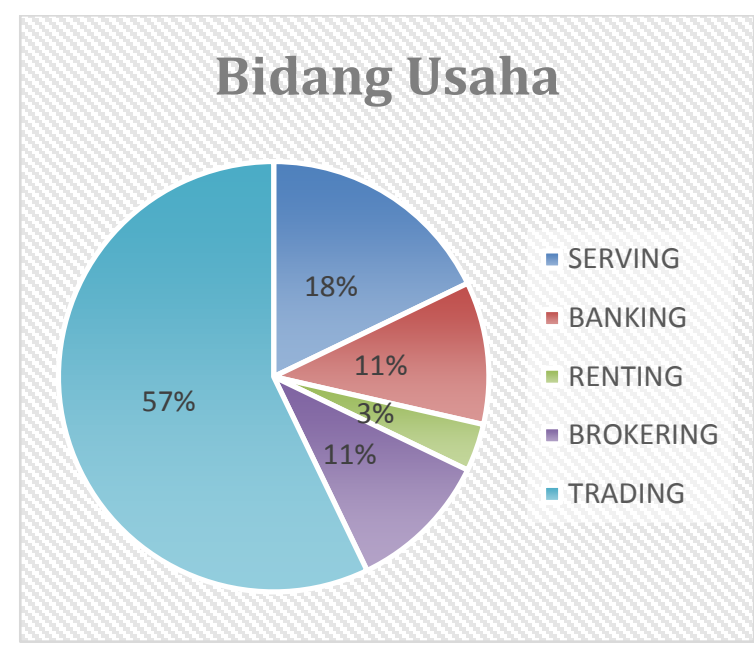

Sumber: Olah data kuesioner responden, 2018

Dokumen perencanaan secara berkala adalah satu output dari fungsi perencanaan. Untuk itu penelitian ini berupaya untuk mengetahui ketersediaan 
${ }^{1}$ Fakultas Ilmu Administrasi, Universitas Indonesia

${ }^{2}$ Lembaga Ilmu Pengetahuan Indonesia

${ }^{3}$ Fakultas Ilmu Administrasi, Universitas Indonesia

dokumen perencanaan dalam BUMDes. Hasil survei menunjukkan bahwa mayoritas BUMDes memiliki dokumen rencana strategis. Mengingat perencanaan adalah akar dalam fungsi manajemen, ketiadaan dokumen rencana strategis dari sebagian BUMDes responden ini menunjukkan bahwa proses awal fungsi manajemen masih belum berjalan.

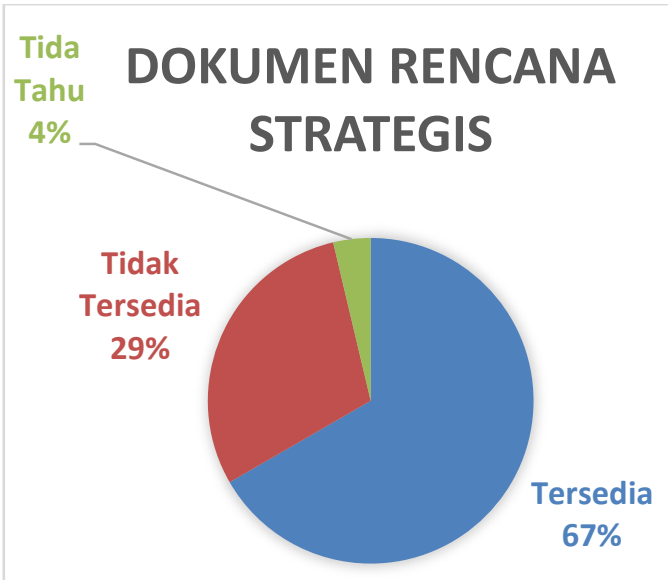

Sumber: Olah data kuesioner responden, 2018

Indikator selanjutnya yaitu tersedianya dokumen rencana strategis yang memuat visi dan misi. Visi dan misi tersebut adalah goal setting atau tujuan yang akan dicapai oleh organisasi. Hasil survei menunjukkan bahwa mayoritas BUMDes sudah menyusun visi misi dalam dokumen rencana mereka. Penyusunan visi dan misi adalah bagian dasar dalam fungsi manajemen karena perencanaan visi dan misi ini akan menjadi dasar fungsi manajemen selanjutnya yaitu fungsi pengorganisasian, pemimpinan, dan pengawasan. Hasil survei menunjukkan bahwa masih terdapat 11\% BUMDes yang tidak memiliki tujuan organisasi. Baik dalam menyusun perencanaan komprehensif maupun strategis, sebuah organisasi harus menyusun tujuan yang menjadi panduan bagi pelaksanaan fungsi manajemen (Halachmi, 1986: 39).

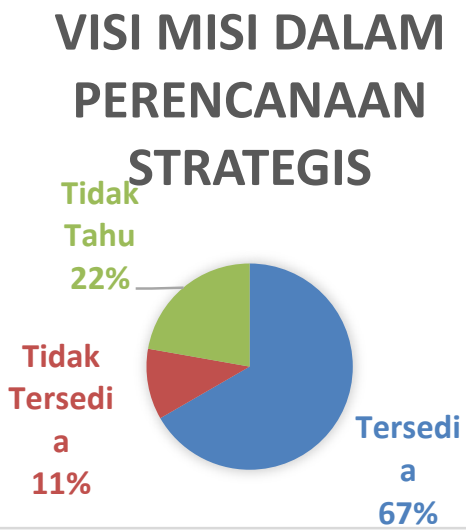

Sumber: Olah data kuesioner responden, 2018

Kemudian, indikator tersedianya formulasi startegi dalam dokumen perencanaan menjadi indikator lanjutan dari adanya visi dan misi. Adanya formulasi strategi menunjukkan adanya upaya untuk mencapai tujuan yang telah ditentukan. Hasil survei menunjukkan bahwa terdapat $56 \%$ responden yang menyatakan adanya formulasi strategi dalam fungsi perencanaan. Formulasi strategi dapat menjadi dasar dalam penentuan jenis usaha dan metode pengembangan usaha. Berdasarkan identifikasi jenis usaha, masih terbatas jumlah usaha yang memiliki strategi masif.

Akan tetapi terdapat satu jenis usaha yang inovatif yaitu gula semut yang dapat menjadi unit usaha inovatif. Untuk mendukung keberhasilan pengorganisasian jenis usaha ini maka perlu ada penyusunan 
${ }^{1}$ Fakultas Ilmu Administrasi, Universitas Indonesia

${ }^{2}$ Lembaga Ilmu Pengetahuan Indonesia

${ }^{3}$ Fakultas Ilmu Administrasi, Universitas Indonesia

strategi yang sesuai dan inovatif. Penyusunan strategi yang tepat dalam sebuah fungsi perencanaan sangat penting karena esensi dari perencanaan tidak hanya penyusunan rencana anggaran dan sumber daya tetapi melibatkan sebuah penilaian yang menyeluruh atas lingkungan dan organisasi sehingga dapat tersusun strategi yang dapat mengatasi masalah yang dihadapi (Hendrick, 2010: 222).

\section{FORMULASI STRATEGI}

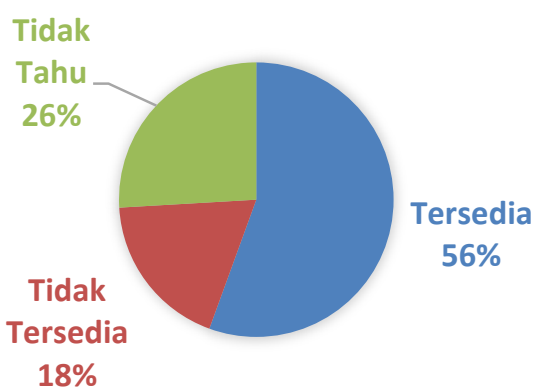

Sumber: Olah data kuesioner responden, 2018

Terakhir adalah adanya perencanaan anggaran BUMDes sebagai bagian upaya untuk menjaga kesinambungan fungsi manajemen. Hasil survei menunjukkan bahwa mayoritas sudah menyusun rencana anggaran dalam fungsi perencanaan. Namun demikian ketersediaan rencana anggaran ini belum dapat memastikan keberhasilan dalam operasionalisasi BUMDes. Hal ini terbukti dengan masih terbatasnya omset yang dimiliki oleh responden. Hasil survei menunjukkan bahwa omset responden yang lebih dari satu juta rupiah setiap bulannya masih terbatas.

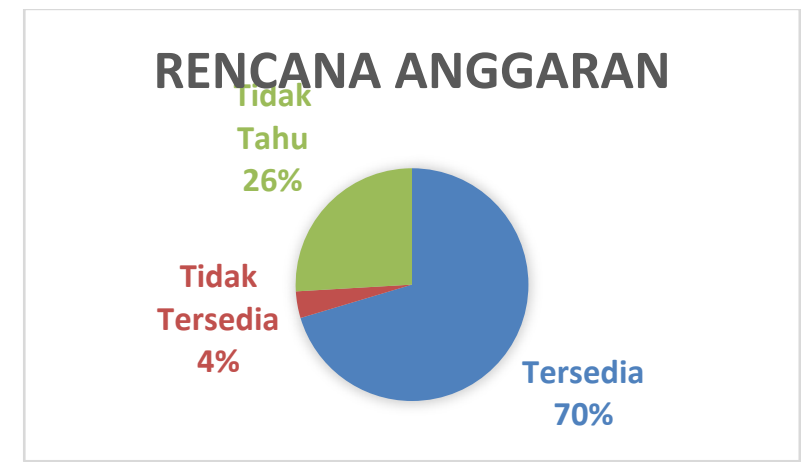

Sumber: Olah data kuesioner responden, 2018

Hasil survei tersebut menunjukkan bahwa fungsi perencanaan ditinjau dari adanya dokumen perencanaan telah terpenuhi. Namun demikian keberhasilan dari visi misi, formulasi startegi, dan anggaran membutuhkan analisis fungsi manajemen selanjutnya yaitu fungsi pengorganisasian, pemimpinan, dan pengawasan.

\section{PENUTUP}

Hasil penelitian menunjukkan bahwa fungsi perencanaan sudah terlaksana dengan ditandai dengan adanya dokumen rencana di sebagian besar responden. Adanya dokumen perencanaan yang memuat visi misi, formulasi strategi, dan rencana anggaran dapat menjadi modal awal dalam manajemen BUMDes. Namun demikian fungsi perencanaan yang tersebut belum dapat menjamin keberhasilan manajemen BUMDes mengingat masih belum besarnya omset, variasi usaha, dan fungsi manajemen lainnya. Fungsi pengorganisasian sebagai upaya pelaksanaan fungsi perencanaan sangat signifikan dalam menentukan keberhasilan 
${ }^{3}$ Fakultas Ilmu Administrasi, Universitas Indonesia

operasional BUMDes di Kabupaten Cianjur.

Penelitian ini memberikan gambaran awal fungsi perencanaan dari fungsi manajemen dalam sebuah organisasi BUMDes. Untuk itu, penelitian lanjutan terkait fungsi manajemen lainnya yaitu fungsi pengorganisasian, fungsi kepemimpinan dan fungsi pengawasan. Tindak lanjut teknis untuk memperkuat fungsi perencanaan yaitu dengan penyediaan tata cara penyusunan strategi berdasarkan visi dan misi sehingga pengembangan BUMDes dapat lebih terarah dengan melibatkan Pemerintah Daerah atau melibatkan proses pembelajaran antar BUMDes.

\section{DAFTAR PUSTAKA}

BeritaCianjur. (2015). Terkendala Modal, Hanya 35 Desa Yang Miliki Bumdes. Download dari http://www. beritacianjur.com/read/4047/terkendal a-modal-hanya-35-desa-yang-milikibumdes

Dariah, Atih Rohaeti. (2009). Peran perguruan tinggi dalam aplikasi variasi model pemberdayaan masyaraat desa di Jawa Barat. MIMBAR Vol XXV No 2 juli Desember: 143-151

Halachmi, Arie. (1986). Strategic Planning and Management? Not Necessarily. Public Productivity Review, Vol. 10, No. 2 , 35-50

Hardijono, R., \& Maryunani, Y. AE, \& Ananda, CF,(2014). Economic Independence of The Village Through Institutional Village Enterprises (BUMDes). IOSR Journal of
Economics and Finance (IOSR-JEF), $3(2), 21-30$

Hendrick, Rebeca. (2010). What is wrong with advice on strategic planning? Public Administration Review, Vol. 70, Supplement to Volume 70: The Future of Public Administration in 2020 pp. S222-S223

Hidayati U. (2015). Performance analysis of village-owned enterprise managers as a basic of designing education and training. European Journal of Business and Management7 (32):143147.

JabarNews. (2017).Bumdes Sukanagalih Cianjur, Targetkan Omset Rp. 5 Miliar. Download dari http://jabarnews.com/2017/07/bumde s-sukanagalih-cianjur-targetkanomset-rp-5-miliar.html

Jones, G \& George. (2007). Essentials of contemporary management. McGraw-Hill Higher Education.

PATTIRO. (2016). Mempertangguh Badan Usaha Milik Desa untuk Menggerakkan Ekonomi Desa. Policy Brief PATTIRO. Jakarta: PATTIRO

Peredo, A. M., \& Chrisman, J. J. (2006). Toward a theory of community-based enterprise. Academy of management Review, 31(2), 309-32

Prafitri, N, Setyoko, I,P. Puspita, RD.(2018). The business management of the village government in managing Village Owned Enterprises. Masyarakat, Kebudayaan dan Politik Vol. 31, Issue 3, 2018

Radar Cianjur. (2017). BUMDes Wajib 
${ }^{1}$ Fakultas Ilmu Administrasi, Universitas Indonesia

2 Lembaga Ilmu Pengetahuan Indonesia

${ }^{3}$ Fakultas Ilmu Administrasi, Universitas Indonesia

Jadi Penggerak Ekonomi Desa di Cianjur. Download dari https://cianjur.pojoksatu.id/baca/bum des-wajib-jadi-penggerak-ekonomidesa-di-cianjur

RadarCianjur. (2016). BUMDes Butuh Dukungan Pemerintah. Download dari

http://www.radarcianjur.co/2016/04/b umdes-butuh-dukungan-

pemerintah.html

Rahman, A. (2015). Peranan Badan USAha Milik Desa (Bumdes) dalam Peningkatan Ekonomi Masyarakat (Studi pada Bumdes Desa Pekan Tebih Kecamatan Kepenuhan Hulu
Kabupaten Rokan Hulu). Jurnal Mahasiswa Prodi Manajemen Fakultas Ekonomi, 2(1).

Ramadana, C. B. (2013). Keberadaan Badan Usaha Milik Desa (BUMDES) sebagai Penguatan Ekonomi Desa. Jurnal Administrasi Publik, 1(6), 1068-1076.

Ridlwan, Z. (2014). Urgensi Badan Usaha Milik Desa(BUMDES) dalam Pembangun Perekonomian Desa. Jurnal Ilmu Hukum, 8(3), 424440.

Robbins, S. P. (2001). Management: Concepts and practices. PrenticeHall. 